\title{
Callus Induction and Differentiation on Melon From In Vitro Culture with The Addition of Indole Acetic Acid and Benzyl Amino Purine Growth Regulator
}

\author{
DOI: $10.18196 / p t .2018 .076 .15-21$
}

\author{
Wiwit Probowati ${ }^{1 *}$ and Budi Setiadi Daryono ${ }^{2}$ \\ ${ }^{1}$ Department of Biotechnology, Universitas Aisyiyah Yogyakarta, \\ Jl. Ring Road Barat 63 Mlangi Nogotirto Gamping Sleman, Yogyakarta, Indonesia, 55292 \\ ${ }^{2}$ Genetics Laboratory, Faculty of Biology, Universitas Gadjah Mada, \\ Jl. Teknika Selatan, Sinduadi, Mlati, Kabupaten Sleman, Yogyakarta, Indonesia, 55281 \\ ${ }^{*}$ Corresponding author, email:wi2t_probo@yahoo.com
}

\begin{abstract}
Melon plants (Cucumis melo L.) are susceptible to disease attacks primarily caused by viruses. One of the viruses often attacking melon plants is Cucumber mosaic virus (CMV). Previous studies have shown that melon callus produced from in vitro culture is detected to have CMV resistance gene (Creb-2). However, the trait of resistance to CMV in that melon (F2) is still segregated. To know the stability of the Creb-2 gene, further research is needed to detect the gene in the differentiated callus. This study aims to callus induce and callus differentiate melon. Firstly, melon seeds were grown on 1/4 MS medium with addition of $2 \mathrm{mg} / \mathrm{L}$ 2.4-Dichlorophenoxyacetate and $1 \mathrm{mg} / \mathrm{L}$ BAP (Benzyl Amino Purine) to grow callus. Secondly, the callus was differentiated in MS medium with the addition of 2,4-D, BAP and IAA in different doses. $0 \mathrm{mg} / \mathrm{L} ; 0.01 \mathrm{mg} / \mathrm{L}$ 2.4-D and $0.1 \mathrm{mg} / \mathrm{L}$ BAP, and MS medium with $0.01 \mathrm{mg} / \mathrm{L} ; 0.1$ $\mathrm{mg} / \mathrm{L} ; 1 \mathrm{mg} / \mathrm{L}$ IAA (lodole Acetic Acid) and $0.1 \mathrm{mg} / \mathrm{L}$ BAP. The results showed that callus was successfully differentiated into root and it grew optimally

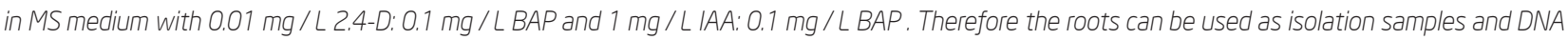
amplification to detect stability of the Creb-2 gene.
\end{abstract}

Keywords: Cucumis melo L., Callus, CMV, In Vitro

\section{ABSTRAK}

Tanaman melon (Cucumis melo L.) rentan terhadap serangan penyakit yang terutama disebabkan oleh virus. Salah satu virus yang sering menyerang tanaman melon adalah Cucumber mosaic virus (CMV). Penelitian sebelumnya telah menunjukkan bahwa kalus melon yang dihasilkan dari kultur in vitro dideteksi memiliki gen ketahanan CMV (Creb-2). Namun, sifat resistensi terhadap CMV dalam melon (F2) masih terpisah. Untuk mengetahui stabilitas gen Creb-2, penelitian lebih lanjut diperlukan untuk mendeteksi gen dalam kalus yang berbeda. Penelitian ini bertujuan untuk menginduksi kalus dan kalus membedakan melon. Pertama, biji melon ditanam pada medium MS dengan penambahan 2 mg / L 2,4-Dichlorophenoxyacetate dan 1 mg / L BAP (Benzyl Amino Purine) untuk menumbuhkan kalus. Kedua, kalus dibedakan dalam medium MS dengan penambahan 2,4-D, BAP dan IAA dalam dosis yang berbeda. 0 mg / L; 0,01 mg / L 2,4-D dan 0,1 mg / L BAP, dan media MS dengan 0,01 mg / L; 0,1 mg / L; 1 mg / L IAA (lodole Acetic Acid) dan 0,1 mg / L BAP. Hasil penelitian menunjukkan bahwa kalus berhasil dibedakan menjadi akar dan tumbuh optimal dalam medium MS dengan 0,01 mg / L 2,4-D: 0,1 mg / L BAP dan 1 mg / L IAA: 0,1 mg / L BAP. Oleh karena itu akar dapat digunakan sebagai sampel isolasi dan amplifikasi DNA untuk mendeteksi stabilitas gen Creb-2..

Kata Kunci: Cucumis melo L., Kalus, CMV, In Vitro

\section{INTRODUCTION}

Melon plant (Cucumis melo L.) is a horticultural from free radicals (Daryono dan Maryanto, 2017). crop that has long been developed in Indonesia Melon comes from the Mediterranean areas since in the early 80 's. Melon is usually consumed as fresh fruit, but it can also be served as beverages, (Asian border with Europe and Africa). Until now, and even melons are sometimes used as flavorings in various food and beverage products. The nutritional content of melon fruit is calcium, phosphorus, iron, Vitamin C, Vitamin A and Vitamin B1 as well as protein. Meanwhile, high content of carotenoid in melon fruit can protect the body cells melon varieties originating from different countries such as Taiwan, China, Japan, France and Denmark have been widely developed. In the 1990s, various new varieties have also been developed, and melon cultivation centers have also spread in several areas in Indonesia, namely: Jakarta, West Java, Yogyakarta, Central Java and East Java. 
However, these melon plants are susceptible to pest infections and disease so that appropriate care and suitable environmental conditions are needed (Somowiyarjo et al., 1993).

Disease attacking melon plants derived from imported seeds are often caused by viruses, one of which is Cucumber mosaic virus (CMV). Among viruses causing the plant diseases, $\mathrm{CMV}$ is one of the dangerous viruses in Indonesia that causes a decrease in production of melon as well as other Cucurbitaceae plants. In addition, the virus attacks can be in the form of Zucchini yellow mosaic virus (ZYMV), Watermelon mosaic virus (WMV), and Papaya ring-spot strain Virus of the watermelon (PRSV-W) (Somowiyarjo et.al., 1993).

The offspring obtained from hybridization between cultivar Yamatouri and Vakharman are reported to have resistance to CMV (Daryono and Natsuaki, 2003). Those melon cultivars have a resistance gene against CMV (Creb-2) inherited to its $\mathrm{F}_{2}$ offspring. However, the resistance to $\mathrm{CMV}$ in this $F_{2}$ melon is still segregated. On the other hand, in vitro culture techniques are often used to produce seeds to produce a uniform character.

Rahmat (2009) proves the detection of resistance genes against Cucumber Mosaic Virus (Creb-2) on melon callus cells (C. melo L.) produced from in vitro culture. According to Wetter and Constabel (2011), induction of differentiation can be done by adding growth regulators of auxin and cytokinin to the culture medium. The optimum concentration of growth regulator to induce callus formation in the study was $2 \mathrm{mg} / \mathrm{L}$ 2.4-D (2,4-dichlorophenoxyacetic acid): $1 \mathrm{mg} / \mathrm{L}$ BAP (N6-benzylaminopurine). Detection of resistance gene to CMV (Creb-2) in the differentiated cell in the form of buds, roots and plantlets of melon produced from in vitro culture had not been done.

The objectives of this study were (1) to determine the optimum concentration of growth regula- tor substances to induced melon cotiledons, and (2) to determine the optimum concentration of growth regulator substances to differentiate melon callus.

\section{MATERIALS AND METHODS}

In vitro culture of melon, DNA isolation and data processing were conducted at the Plant Tissue Culture Laboratory and Genetics Laboratory of the Faculty of Biology, Gadjah Mada University (Latitude: -7.7663471933499 - Longitude: 110.37653248888). $F_{2}$ melon seeds resulted from the hybridization between Yamatouri and Vakharman were obtained from Genetics Laboratory, Faculty of Biology UGM (Latitude: - 7.7663471933499 - Longitude: 110.37653248888)

\section{In Vitro Culture}

$\mathrm{F}_{2}$ melon seeds were germinated in $1 / 4 \mathrm{MS}$ (Murashige \& Skoog) medium. Callus induction from cotyledon was performed in germination medium added with 2,4-D: BAP $=2: 1 \mathrm{mg} / \mathrm{L}$. Cotyledon was induced for up to 2 weeks. Callus differentiation was then performed on MS medium with the addition of BAP and NAA at $0-2 \mathrm{mg} /$ L concentration level. According to Tabei et al. (1991), there was also differentiation of callus on MS medium with addition of 2,4-D by 0 to 0.01 $\mathrm{mg} / \mathrm{L}$ and BAP $0.1 \mathrm{mg} / \mathrm{L}$, and addition of IAA of $0.01 \mathrm{mg} / \mathrm{L} ; 0.1 \mathrm{mg} / \mathrm{L} ; 1 \mathrm{mg} / \mathrm{L}$ and BAP of $0.1 \mathrm{mg} / \mathrm{L}$. All media were arranged to be in the $\mathrm{pH}$ range of 5.6-6.3 and sterilized by autoclave at $120^{\circ} \mathrm{C}$ for 2 hours.

\section{RESULTS AND DISCUSSIONS}

Callus induced

Rahmat (2009) reported that MS medium with addition of 2.4-D: BAP $=2: 1 \mathrm{mg} / \mathrm{L}$ is the optimal medium for induction of melon callus using cotyledon explants. So in this research also used the comparison of hormone concentrations. 
Callus morphology observed includes the color, size and texture of the callus. The combination of various growth regulators has resulted in white, brownish, diverse, and crumbly to compact textures. The best callus with callus size, color and texture parameters in Rahmat (2009) study is a variation of the growth regulators addition of 2 $\mathrm{mg} / \mathrm{L}$ 2.4-D: $1 \mathrm{mg} / \mathrm{L}$ BAP. Callus treatment in $2 \mathrm{mg} / 1$ 2.4-D: $1 \mathrm{mg} / 1$ BAP has a slightly greenish green callus morphology, callus grows well and covers explants all over the surface so that eksplan is not visible anymore and callus looks compact. In addition of $2 \mathrm{mg} / \mathrm{L} 2,4-\mathrm{D}: 1 \mathrm{mg} / \mathrm{L}$ BAP, the optimum callus growth was developed, the callus was formed rapidly.

To induce this callus used source explant of cotyledon from sprouts melon plants grown in vitro. From one cotyledon is divided into four parts then planted into MS medium which has been added variation of growth regulator treatment. Cotyledon is a food reserve for the growth of sprouts that are young organs so it will be easy to be dedifferent to callus. Dedifferentiation allows adult cells to return to a youthful state that is meristematically active dividing. In young cells it can be intensive cell division and the growth potential is higher than in adult cells. In young cells can also occur regeneration to form organs and embryos.

\section{Callus Differentiation}

In this study, two experiments were applying addition of growth regulators. In the first experiment, differentiation was performed by adding cytokinin and auxin that is BAP: NAA at a concentration level of 0-2 mg / L. Observations were made after 5 weeks of planting. The result showed that there was no differentiated callus in response to the addition of the growth regulator. Response was in the form of callus growing continuously. Except for MS medium with BAP: $\mathrm{NAA}=0: 0$ which is considered as control in which callus differentiated into root.

In Table 1, it can be seen that melon callus in medium containing cytokinin (BAP) without auxin (NAA) had strong (compact) callus morphology and green callus. Besides, the callus grew more slowly compared to the growth of callus given auxin. Meanwhile, giving a single auxin makes the callus growth faster so that the callus has larger size and white color . Cytokinin is only active if there is auxin, cytokinin together with auxin to culture medium can spur cell division and morphogenesis. Cytokinin affects the auxin transport, lateral bud growth (breaking apical dominance), leaf development, leaf aging process inhibition and chloroplast development (Neumann et al., 2009).

Table 1. Morphology of Melon Callus Growth Produced from In Vitro Differentiation (5 Weeks)

\begin{tabular}{cccccc}
\hline NAA / BAP & 0 & 0.5 & 1 & 1.5 & 2 \\
\hline 0 & hk** & Hhkk & Hhkk & hhkk & hhkk \\
0.5 & $+p r$ & $+p h r$ & Phr & phr & phhr \\
1 & $++p r$ & $+p r$ & Phr & phrr & phrr \\
1.5 & $++p r$ & $++p r$ & $+p r r$ & + prr & prr \\
2 & $+++p r$ & $++p r$ & $+p r r$ & $+p r r$ & + prrr \\
\hline
\end{tabular}

Note:

$+\quad$ : callus size

$p$ : white

h : green

c : brown

k : hard

$r$ : scatter

: root growing

No response of differentiation from the addition of growth regulator gives the supposition that the concentration of growth regulating agent given is too high to induce the callus. George and Sherrington (2004), mention that common synthetic auxin is used with a maximum concentration of 2 $\mathrm{mg} / \mathrm{L}$, a very high auxin is herbicide for plants, but the effect is different in each plant species. Not only the concentration of auxin is too high but also the concentration of cytokinin that is too high, in this case BAP. Giving high BAP resulted in green 
colored callus since the function of cytokinin is to influence the formation of chloroplast.

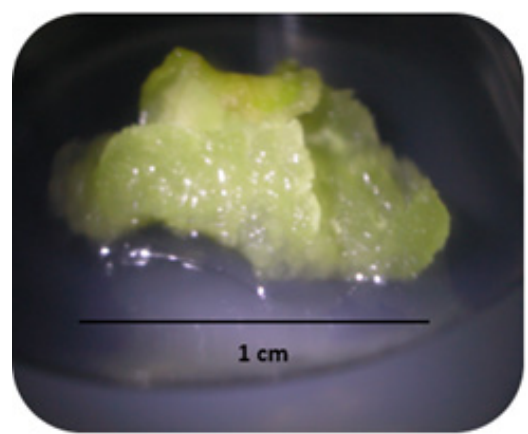

Figure 1. Growth of Melon Callus on MS Medium 2.4-D: BAP = 2: $1 \mathrm{mg} / \mathrm{L}$ for 3 Week

Based on Figure 1, it can be seen that callus on media without growth regulator substances can differentiate into root because there is influence of callus endogenous hormone (Auxin). Neumann et al. (2009) explain that in tissue culture, endogenous hormones contained in a plant also play a role in growth and development of the plan including differentiation. Adding certain exogenous hormones is done to get specific goals such as growth of buds, root growth and regeneration into plants.

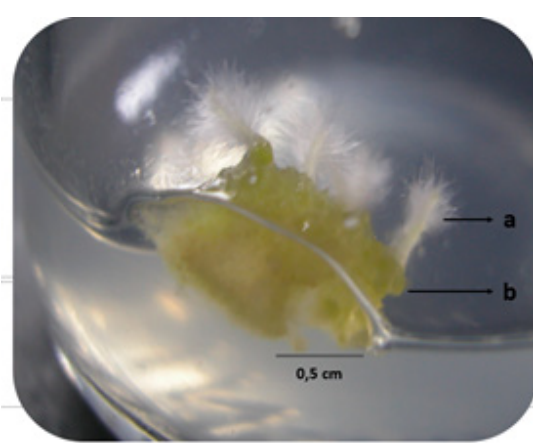

Figure 2. Root growth of callus in MS medium without addition of growth regulator (BAP: NAA $=0: 0$ )

Roots start appearing 2 weeks after planting. The differentiation process from callus to root is slow. After 5 weeks the roots do not grow anymore and the root morphology is just a cell bulge like a root hair or called protuberance. The differen- tiation in the form of protuberance cannot be said to be a true root. Protuberance is a form of morphological variation seen on the callus. Some experts believe that protuberance is formed only as a mechanical consequence due to the development of intercellular space which has no apparent function (Machado, 2000). Therefore the form of differentiation cannot be used for DNA isolation.

To obtain the differentiation form of callus, the study continued with the addition of growth regulators at smaller concentrations, in addition the auxin groups were replaced by 2,4-D and IAA. According to Table et al. (1991), addition of auxin and cytokinin at low concentrations can regenerate calluses into plantlets. The result obtained was the differentiation of callus into root.

Based on Figure 3, callus planting was done on MS medium with addition of 2.4-D: $\mathrm{BAP}=0: 0.1$ $\mathrm{mg} / \mathrm{L}$ and 2.4-D: BAP $=0.01: 0.1 \mathrm{mg} / \mathrm{L}$. Differentiation could occur 2 weeks after planting. In both types of medium there was callus differentiation response. However, callus differentiation stopped after 2 weeks in MS medium containing 2,4-D: $\mathrm{BAP}=0: 0.1$. While in MS medium 2.4-D: $\mathrm{BAP}=0.01: 0.1$, callus kept differentiating into root. So the roots used for DNA isolation were only roots derived from MS medium containing 2.4-D: $\mathrm{BAP}=0.01: 0.1$.

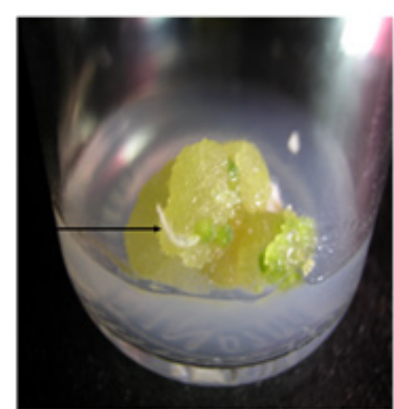

1

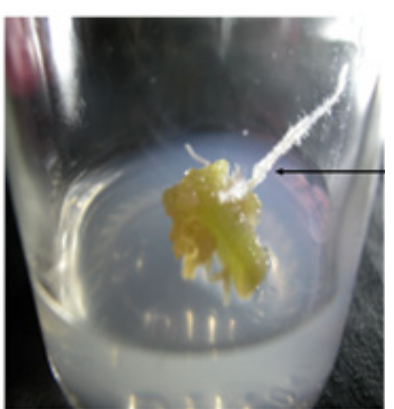

2
Figure 3. Callus differentiation into root on MS medium with addition of growth regulator (1 = MS 2.4-D: BAP = 0: $0.1 \mathrm{mg} /$ $L$ and $2=$ MS 2.4-D: BAP $=0.01: 0.1 \mathrm{mg} / \mathrm{L}$ ) for 2 weeks. The arrows point to the growing roots 


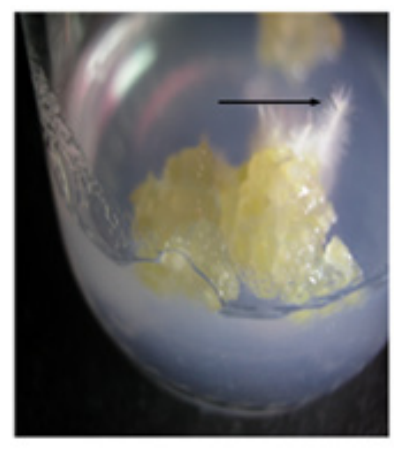

1

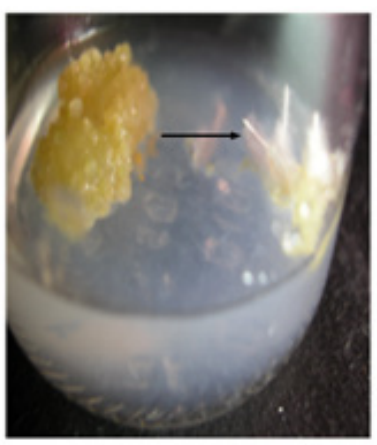

2

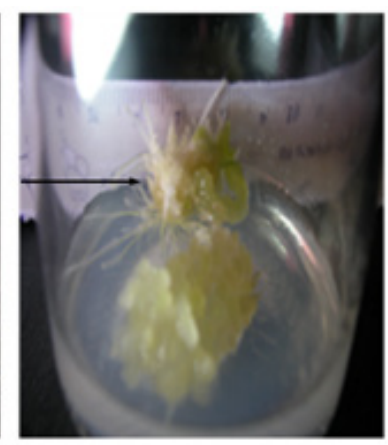

3

Figure 4. Callus differentiation into root in MS medium with addition of growth regulator $(1=\mathrm{IAA}: \mathrm{BAP}=0.01: 0.1 \mathrm{mg} / \mathrm{L}, 2$ $=I A A: B A P=0.1: 0.1 \mathrm{mg} / \mathrm{L}$ and $3=I A A: B A P=1: 0.1 \mathrm{mg} / \mathrm{L})$ for 2 weeks. The arrows point to the growing roots.

Figure 4 shows the differentiation of callus into root in MS medium with addition of IAA: BAP = 0.01: $0.1 \mathrm{mg} / \mathrm{L}$, MS IAA: BAP = 0.1: $0.1 \mathrm{mg} / \mathrm{L}$ and MS IAA: BAP $=1: 0.1 \mathrm{mg} / \mathrm{L}$. Roots grown from callus in MS medium containing IAA : BAP $=0.01: 0.1$ and IAA: BAP $=0.1: 0.1$ stopped growing after two weeks so the roots could not be used for DNA isolation. While roots that grew on MS medium containing IAA : $\mathrm{BAP}=1: 0.1$ could continue to grow until the real root was formed.

The root used for DNA isolation was the growing root from MS medium with the addition of 2.4-D: $\mathrm{BAP}=0.01: 0.1 \mathrm{mg} / \mathrm{L}$ and IAA: $\mathrm{BAP}=$ $1: 0.1 \mathrm{mg} / \mathrm{L}$ that is roots that grew and had true root morphology which was not just the root hairs. MS medium with addition of 2.4-D : $\mathrm{BAP}=0.01$ : $0.1 \mathrm{mg} / \mathrm{L}$ and IAA: BAP $=1: 0.1 \mathrm{mg} / \mathrm{L}$ was the most optimum medium to differentiate melon callus into root organ.

According to Neumann et al. (2009), auxin such as NAA, IAA and 2,4-D are differentiated based on their chemical and metabolic resistance in inactivating cells. IAA is the most labile hormone to temperature and most rapidly experiencing photo oxidation. Meanwhile NAA has more stable properties and 2,4-D is the most stable to temperature. However, some melon cell culture research (Selvaraj, 2006; Tabei et al., 1991 Moreno et al., 1985) state that the use of IAA as one component of growth regulator substances can regenerate callus into plantlet. The results of this study prove that the use of IAA can differentiate callus into root.

Soma-clonal variation can be defined as clonal variation that occurs in culture cell due to epigenetic factors. In cell culture of the plant there are 10,000 to 15,000 cells or more that have genetic mutation so that they can be different from the stem cell. Changes in ploidy levels in cell culture and some epigenetic variations such as mutations, alteration of arrangement and number of chromosomes, gene amplification and transposing activation can be categorized as soma-clonal variations. A form of cell differentiation will decrease the degree of soma-clonal variation and a mechanism of directional genetic stability (Larkin and Scowcroft, 1981). In this study, it can be said that roots have lower soma-clonal variation rates because the cells are already organized and have directional growth. The existence of directed genetic mechanism at the differentiation process leads to the occurrence of genetic stability. Therefore the roots can be used as isolation samples and DNA amplification.

According to Hiray and Amemiya (1989), CMV resistance gene expression is produced in multicellular phase rather than single cell. Resistance gene expression can be known after the cell is infected 
with the virus and it requires the presence of other adjacent cells to be able to provide a defense response. It takes intercellular space between one cell and another cell to be able to provide an inhibitory response of virus replication. Hirai and Amemiya (1990) added that defense may also involve cellular membrane changes that block the diffusion and transport of virus particles from cell to cell. However, the mechanism of inhibiting the spread of the virus in a resistant cultivar until now is not known for certain and is still investigated further.

$\mathrm{F}_{2}$ of melon used in this study was the result of a crossing between melon cv. Yamatouri and Vakharman. Based on the results of Daryono et al. (2003), research on the resistance of honeydew to the virus revealed that from the total of 63 honeydew cultivars studied, there were 5 cultivars namely Yamatouri, Miyamauri, Mawatauri, Sanukishirouri, and Shinjong were resistant to CMV-B2. cultivar Yamatouri was resistant to CMV-B2 and CMV-lace. In contrast, cultivar Vakharman was not resistant to either CMV-B2 or CMV-lace nor even resistant to other Cucurbitaceae viruses such as CGMMV, KGMMV and PRSV-W. The crossing between the two cultivars aimed to get a melon plant that was resistant to the virus producing qualified fruit.

\section{CONCLUSIONS}

1. Callus produced from melon seeds on MS medium is optimally obtained with the addition of 2.4-D:BAP=2:1 mg/L.

2. The differentiated callus in the form of root is optimally obtained with the addition of 2,4-D: $\mathrm{BAP}=0,01: 0,1 \mathrm{mg} / \mathrm{L}$ and IAA: $\mathrm{BAP}=1: 0$, $1 \mathrm{mg} / \mathrm{L}$.

\section{ACKNOWLEDGMENT}

This research was supported by Competing Grant Ministry of Research and Technology and higher education 2008 for research and development programme Project to the second author.

\section{REFERENCES}

Daryono, B.S., S. Somowiyarjo, and K.T. Natsuaki, 2003. New source of resistance to Cucumber mosaic virus in melon. SABRAO Journal of Breeding and Genetics. 35: 19-26.

Daryono, B.S., K. Wakui, and K.T. Natsuaki.2005. Isolation and characterization of molecular markers linked to CMV-B2 resistance gene in melon.J.Phytopathol. 71: 278.

Daryono, B. S. 2009. Development and Application of Melon Resistance Gene Analog (MRGA) Markers for Detection of Virus Resistance Gene in Melon (Unpublished). Faculty of Biology Gadjah Mada University. Yogyakarta.

Daryono, B.S. dan S.D. Maryanto. 2017. Keanekaragaman dan potensi Sumber Daya Genetik Melon. UGM Press. Yogyakarta.

George, E. F., and P.D. Sherrington. 2004. Plant Propagation by Tissue Culture. Exegetics Ltd. England.

Hirai, S., and Y. Amemiya.1989. Studies on the resistance of melon cultivars to cucumber mosaic virus (I) virus multiplication in leaves or mesophyll protoplasts from a susceptible and resistant cultivars. Ann. Phytopath. Soc. Japan 55: 458-465.

Hirai, S., and Y. Amemiya. 1990. Studies on the resistance of melon cultivars to cucumber mosaic virus (II) RNA profiles of virus multiplied in resistant and susceptible cultivars. Ann. Phytopath. Soc. Japan 56: 39-46.

Larkin, S. and W. Snowcroft. 1981. Somaclonal variation-a novel source of variability from cell cultures for plant improvement. Theor. Appl. Genet 60:197-214

Machado, S. R., M. E.M. Estelita, and E. A. Gregorio. 2000. Ultrastructure of the intercellular protuberances in leaves of Paepalanthus Superbus. Ruhl (Eriocaulaceae). Revista Brasileira de Botânica. 23 (4): 100-111.

Moreno,V., M. Garcia-Sogo, I. Granell, B. Garcia-Sogo, and L. A. Roig. 1985. Plant regeneration from calli of melon (Cucumis melo L.,Cv. 'Amarillo Oro'). Plant Cell Tissue Organ Culture. 5:139146. 139

Neumann, K.H., A. Kumar, and J. Imani. 2009. Plant Cell and Tissue Culture-A Tool in Biotechnology. Springer-Verlag Berlin Heidelberg. Jerman. pp.75-83. http://www.ebookee.com/ Plant-Cell-and-Tisssue-Culture-A-Tool-in-Bio technology-Basicand-Aplication-274066.html

Rahmat. 2009. Isolasi dan Amplifikasi Gen Ketahanan terhadap Cucumber Mosaic Virus (Creb-2) pada Sel-Sel Kalus Melon (Cucumis melol.) Hasil Kultur In Vitro. Skripsi. Fakultas Biologi. Universitas Gadjah Mada. Yogyakarta. 
Selvaraj, N., A. Vasudevan, M. Manickavasagam, and A. Ganapathi. 2006. In vitro organogenesis and plant formation in cucumber. Biologia Plantarum 50:123-126.

Somowiyarjo, S., N. Sako, and K. Tomaru. 1993. The use of dot immunobinding assay for detecting cucurbit viruses in Yogyakarta. In: Production of virus-free tropical crops. Editor : Tomaru, K. and Natsuaki, K.T. NODAl Center for International Programs. Tokyo University of Agriculture. Tokyo. pp. 3-11.

Tabei, Y., T. Kanno, and T. Nihio. 1991. Regulation of organogenesis and somatic embryogenesis by auxyn in melon, Cucumis melo L. Plant cell report. Springer-Verlag. 10:225-229.

Wetter, L. R., and F. Constabel. 2011. Metode Kultur Jaringan Tumbuhan. Edisi ke-4. Penerbit ITB. Bandung. pp. 1-3, 14,18-20. 